\title{
Local Changes of IGF-I mRNA, GH Receptor mRNA, and Fiber Size in Rat Plantaris Muscle Following Compensatory Overload
}

\author{
Akihiko YAMAGUCHI, Yasuhiro IKEDA*, Toshihiro HIRAI*, \\ Takahiko FUJIKAWA ${ }^{\dagger}$, and Isao MORITA ${ }^{\ddagger}$ \\ Department of Integrated Human Sciences and \\ * Department of Removable Prosthodontics, School of Dentistry, Health Sciences University \\ of Hokkaido, Tobetsu-cho, Ishikari-gun, Hokkaido, 061-0293 Japan; \\ † Department of Biochemistry, Mie University School of Medicine, \\ Tsu, 514-8507 Japan; and \\ ‡ Department of Integrated Human Sciences, School of Nursing and Social Services, \\ Health Sciences University of Hokkaido, Tobetsu-cho, \\ Ishikari-gun, Hokkaido, 061-0293, Japan
}

\begin{abstract}
We investigated whether local insulin-like growth factor-I (IGF-I) mRNA and growth hormone $(\mathrm{GH})$ receptor mRNA expressions in plantaris muscle were related to the region-specific hypertrophy following compensatory overload. Adult male normal or hypophysectomized rats were subjected to unilateral distal-half removals of the gastrocnemius and soleus muscles. The contralateral hindlimb was used as the control. Two weeks later, fiber areas in the distal and proximal parts of the plantaris muscle were measured. All the fiber areas measured in the distal part of the plantaris muscle in normal and hypophysectomized rats were significantly increased following the compensatory overload. In the proximal part, fiber areas of type I, IIA, and IIC were significantly increased, but fiber area of type IIB did not change. IGF-I mRNA expressions in the distal and proximal
\end{abstract}

parts were increased $3 d$ after the compensatory overload in normal and hypophysectomized rats. The increase of IGF-I mRNA expression in the distal part $3 d$ after compensatory overload was greater than those in the proximal part. IGF-I mRNA expressions in the distal and proximal parts were increased $14 \mathrm{~d}$ after the compensatory overload in hypophysectomized rats, but not in normal rats. GH receptor mRNA expressions were decreased following compensatory overload, and almost disappeared $14 \mathrm{~d}$ after the compensatory overload in hypophysectomized rats. Thus muscle fiber hypertrophy following compensatory overload was different among the parts in a muscle and IGF-I mRNA was expressed in concert with the region-specific hypertrophy, but not $\mathrm{GH}$ receptor mRNA. [Japanese Journal of Physiology, 53, 53-60, 2003]

Key words: IGF-I, GH receptor, hypertrophy, hypophysectomy, muscle fiber.

Skeletal muscle is hypertrophied by compensatory overload [1-3]. The magnitude of the hypertrophy after compensatory overload is different between the regions in a rodent muscle [4]. In humans, region-specific hypertrophy exists in consecutive cross-sectional areas of the elbow flexors [5]. Region-specific hypertrophy in a muscle is related to the different muscle fiber recruitment pattern [6, 7]. However, what causes region-specific hypertrophy is unclear.

Many studies have shown that growth hormone

Received on September 5, 2002; accepted on December 17, 2002

Correspondence should be addressed to: Akihiko Yamaguchi, Department of General Education, Health Sciences University of Hokkaido, Kanazawa, Tobetsu-cho, Ishikari-gun, Hokkaido, 061-0293 Japan. Tel: +81-1332-3-1211, Fax: +81-1332-3-1496, E-mail: yama@hokuiryo-u.ac.jp 


\section{A. YAMAGUCHI et al.}

(GH) and insulin-like growth factor-I (IGF-I) have an important role in the growth of skeletal muscle. Growth of skeletal muscle is severely retarded during development in hypophysectomized rats $[3,8]$ and administration of GH and IGF-I in hypophysectomized rats restores growth of skeletal muscle [8-10]. Generally, GH is thought to stimulate the growth of skeletal muscle by way of IGF-I mainly produced in the liver. Also, GH may contribute directly to the growth of skeletal muscle, as local injections of GH stimulate muscle growth [11] and the expression of GH receptor mRNA is increased in regenerating muscle [12]. IGFI contributes to the growth of skeletal muscle due to GH-dependent endocrine action, as well as GH-independent autocrine/paracrine action [13-15]. Thus, there is a possibility of GH and IGF-I being associated with the region-specific hypertrophy, however, the relationships between GH or IGF-I and the regionspecific hypertrophy have not been investigated.

Isgaard et al. [12] reported that GH receptor mRNA expression enhanced in volume overloaded cardiac muscle. Jennische and Andersson [16] showed that the expression of GH receptor mRNA increases in regenerating skeletal muscle after ischemic damage. These observations suggest that GH receptor may be related to muscle growth during various conditions, included compensatory overload. However, GH receptor mRNA expression during compensatory overload is not investigated, and whether muscle hypertrophy after compensatory overload is related to the expression of the $\mathrm{GH}$ receptor remains unclear.

Consequently, this study attempted to measure IGFI mRNA and GH receptor mRNA expressions on the region-specific hypertrophy in plantaris muscle after compensatory overload.

\section{MATERIALS AND METHODS}

Animal care and surgical procedures. Male Wistar strain rats weighing $\sim 170 \mathrm{~g}$ were used. Twelve rats were subjected to a hypophysectomy operation at 10 weeks of age (hypox rats). Twelve other rats were used as the control (normal rats). One week later, all rats suffered from compensatory overload of the plantaris muscle by unilateral removals of the gastrocnemius and soleus muscles (Hypox-OL and Normal$\mathrm{OL})$. The contralateral sham-operated muscles were used as the control (Hypox-Cont, Normal-Cont). All animals were housed in cages at constant room temperature $\left(22 \pm 2^{\circ} \mathrm{C}\right)$ and fed ad libitum. All experiments and procedures were performed according to the Guideline for the Care and Use of Laboratory Animals in Health Sciences University of Hokkaido.
The rats were anesthetized by an intraperitoneal injection of sodium pentobarbital $\left(40 \mathrm{mg} \cdot \mathrm{kg}^{-1}\right.$ body mass). Hypophysectomy was carried out using the transauricular technique described by Koyama [17]. A puncture needle was inserted into the external auditory canal in the anesthetized animals, which pierced the thinner part of the bone wall of the tympanum. The inner cylinder of the injector fixed to the needle was pulled out slightly to create negative pressure and the pituitary body was then aspirated. The pituitary body was identified by the pinkish color of the anterior lobe. Success of the surgical operation was confirmed by direct observation showing the lack of pituitary gland at the end of this experiment.

Compensatory overload was performed by the unilateral distal-half removals of the gastrocnemius and soleus muscles using the modified method described by Ianuzzo and Chen [18]. The ablation operation was initiated with a longitudinal incision through the skin and fascia along the posterior aspect of the tibia. The lateral and medial heads of the gastrocnemius and soleus muscles were carefully isolated by way of blunt dissection and the distal halves of the muscles were removed. Vasculature and nerves associated with the plantaris muscles were carefully preserved.

The plantaris muscles (12 rats of each group) were processed by biochemical and histochemical analyses. Analyses of IGF-I and GH receptor mRNAs were performed at $3 \mathrm{~d}$ ( 5 rats of each group) and $14 \mathrm{~d}$ ( 5 rats of each group) after compensatory overload. Muscle weight and histochemical analyses (7 rats of each group) were performed at $14 \mathrm{~d}$ after compensatory overload.

Histochemistry. Seven rats of each group were sacrificed $14 \mathrm{~d}$ after compensatory overload for histochemical analysis. The plantaris muscle was quickly dissected and freed of any fat and connective tissues, with the wet weights being recorded. The plantaris muscle was then cut transversely at the $1 / 3$ (distal) and $2 / 3$ (proximal) points from the distal tendon and immediately frozen in isopentane cooled to $-130^{\circ} \mathrm{C}$ with liquid nitrogen. Each tissue was cut into $10-\mu \mathrm{m}-$ thick serial sections in a cryostat at $-20^{\circ} \mathrm{C}$. For the identification of muscle fiber types, tissue slices were processed by myofibrillar actomyosin ATPase after preincubation (room temperature) for $4 \mathrm{~min}$ at $\mathrm{pH} 4.3$ and 4.6, and $10 \mathrm{~min}$ at $\mathrm{pH} 10.3$ [19]. Muscle fibers were classified as type I, IIA, IIB, and IIC according to the nomenclature system of Brooke and Kaiser [20]. The areas of each fiber type were determined by counting $\sim 60$ fibers from the cross-sections at the $1 / 3$ and $2 / 3$ points from the distal tendon of the plantaris muscle. The measurements of fiber areas were carried 
out using a Macintosh-based image analyzing system (NIH-image 1.54). Because only a minimal percentage of type IIA fiber in hypox rats was found, it was not included in the analysis of fiber area.

Analyses of IGF-I and GH receptor mRNAs.

Five rats of each group were sacrificed at 3 and $14 \mathrm{~d}$ after compensatory overload for analyses of IGF-I and $\mathrm{GH}$ receptor mRNAs. The plantaris muscle was quickly dissected and freed of any fat and connective tissues. It was then cut transversely at the $1 / 3$ and $2 / 3$ points from the distal tendon. The $1 / 3$ distal part (distal) and $1 / 3$ proximal part (proximal) of the plantaris muscle were immediately frozen in liquid nitrogen and stored at $-80^{\circ} \mathrm{C}$ until used. Total RNA was extracted by the guanidium isothiocyanate-phenol-chloroform method described by Chomczynski and Sacchi [21]. RNA concentrations were determined spectrophotometrically at $260 \mathrm{~nm}$. Ribonuclease protection assays of IGF-I and GH receptor mRNAs were carried out according to the method reported by Fiedberg et al. [22] using the Guadian RNase protection assay kit (Clontech, Palo Alto, CA, USA). ${ }^{32} \mathrm{P}$ radio-labeled 419 base pairs (bp) IGF-I mRNA and $376 \mathrm{bp} \mathrm{GH}$ receptor mRNA riboprobes were used. The riboprobe of GH receptor mRNA was complementary to $152 \mathrm{bp}$ of a common extracellular region to GH-binding protein and GH receptor mRNAs, and to $120 \mathrm{bp}$ of GH-binding protein mRNA specific hydrophilic tail. Thus a $272 \mathrm{bp}$ fragment of the hybridization between the riboprobe and GH-binding protein mRNA as well as a $152 \mathrm{bp}$ fragment of hybridization between the riboprobe and GH receptor mRNA were yielded as described by Fujikawa et al. [23]. Total RNA $(40 \mu \mathrm{g})$ from the muscle was suspended in $30 \mu$ l hybridization buffer containing excess riboprobe. After hybridization at $37^{\circ} \mathrm{C}$ for $60 \mathrm{~min}$, the samples were incubated with RNase $A$ and $T_{1}$ at $37^{\circ} \mathrm{C}$ for $30 \mathrm{~min}$. The RNases were inactivated by digestion with proteinase $\mathrm{K}$ for $15 \mathrm{~min}$, and the protected RNA hybrids were precipitated with $70 \%$ ethanol. The protected fragments were then denatured at $95^{\circ} \mathrm{C}$ for $3 \mathrm{~min}$ in the loading buffer ( $80 \%$ formamide, $0.1 \%$ xylene cyanol, $0.1 \%$ bromophenol blue, and $10 \mathrm{mM}$ EDTA) and electrophoresed in a $6 \%$ acrylamide $-8 \mathrm{M}$ urea gel. Bands corresponding to the probe fragments protected by IGF-I and GH receptor mRNAs were quantified using the NIH image 1.54 system. The data were expressed as a percentage of the value obtained from distal control in normal rats.

Statistics. Standard statistical procedures were employed to calculate the means and standard deviations. Two-way repeated ANOVA was used for the comparison between the groups. Differences between the means were regarded as significant at $p<0.05$.

\section{RESULTS}

Body weights of hypox and normal rats $14 \mathrm{~d}$ after compensatory overload were $160.3 \pm 8.02$ and $252.3 \pm$ $7.62 \mathrm{~g}$, respectively.

Muscle weight and relative weight of plantaris $14 \mathrm{~d}$ after compensatory overload are shown in Fig. 1. Muscle weights of the plantaris in Normal-OL and Hypox-OL groups were significantly heavier than in Normal-Cont and Hypox-Cont groups, respectively (Fig. 1a). Relative weights of plantaris to body weight in Normal-OL and Hypox-OL groups were significantly greater than in Normal-Cont and Hypox-Cont groups, respectively (Fig. 1b). Muscle weights of the plantaris in Hypox-Cont and Hypox-OL groups were significantly lower than in Normal-Cont and NormalOL groups, respectively (Fig. 1a). However, relative weights of plantaris to body weight in Hypox-Cont and Hypox-OL groups did not differ from those in

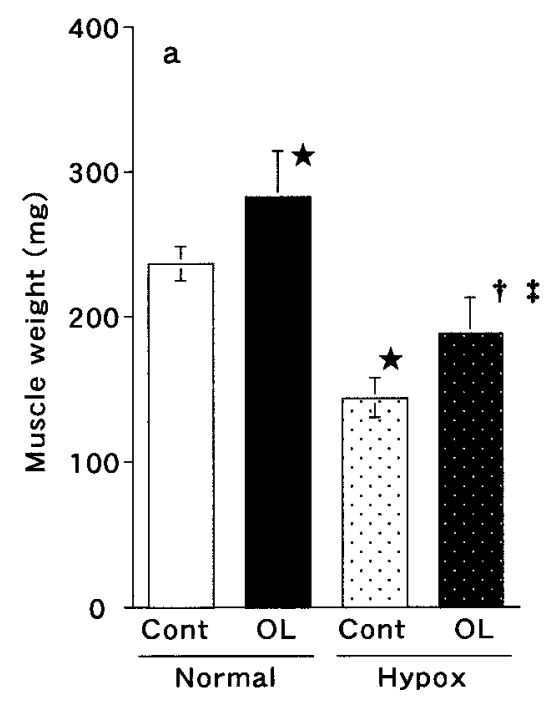

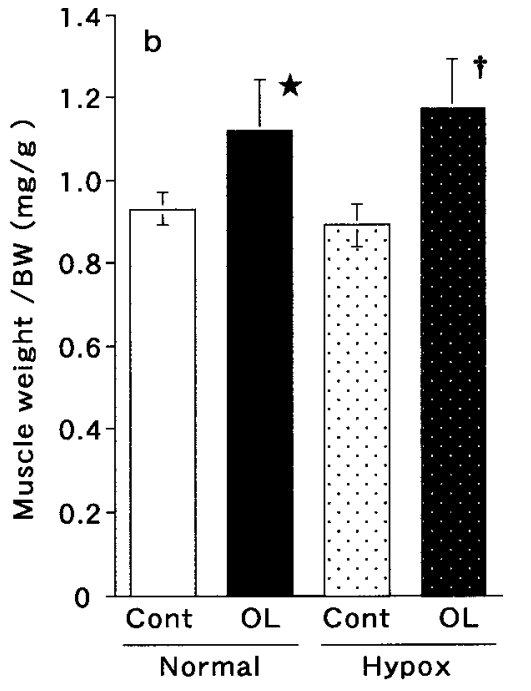

Fig. 1. Muscle weight (a) and the relative weight (b) of plantaris $14 \mathrm{~d}$ after compensatory overload. ${ }^{\star} p<0.05$ vs. Normal-Cont; ${ }^{\dagger} p<0.05$ vs. Hypox-Cont; ${ }^{\ddagger} p<0.05$ vs. Normal-OL. 

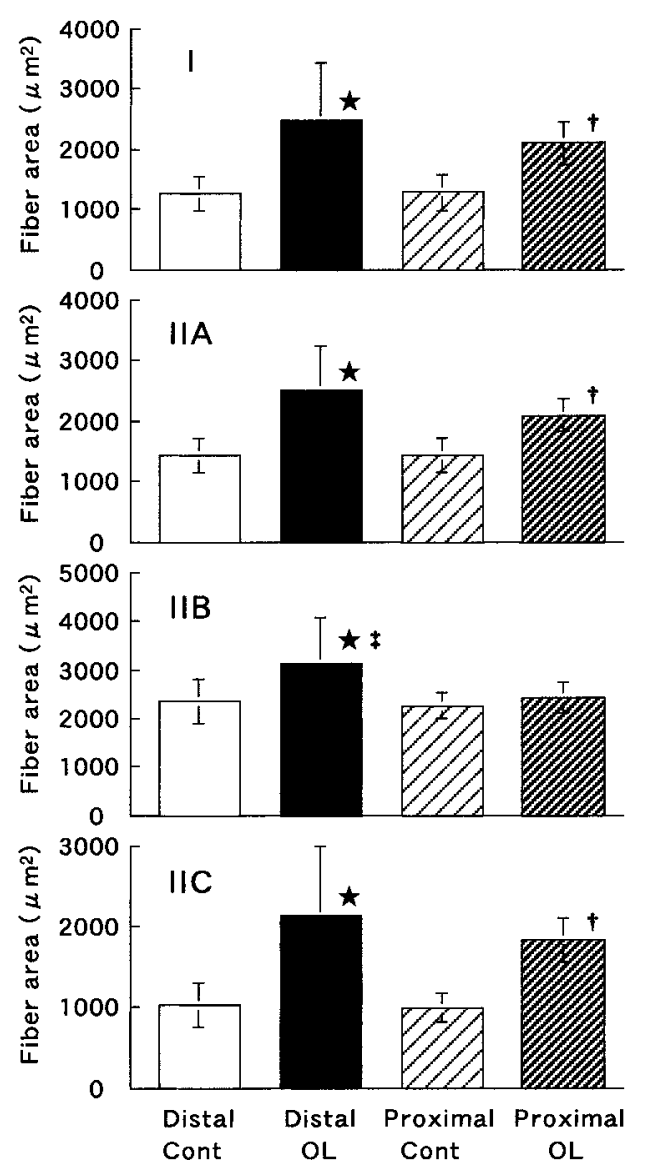

Fig. 2. Muscle fiber areas of plantaris in normal rats $14 \mathbf{d}$ after compensatory overload. ${ }^{\star} p<0.05$ vs. DistalCont; ${ }^{\dagger} p<0.05$ vs. Proximal-Cont; ${ }^{\ddagger} p<0.05$ vs. Proximal-OL.

Normal-Cont and Normal-OL groups, respectively (Fig. 1b).

Fiber areas of the plantaris muscle in normal rats $14 \mathrm{~d}$ after compensatory overload are shown in Fig. 2. Fiber areas of type I, IIA, IIB, and IIC in the distal part of Normal-OL group were significantly larger than Normal-Cont group (Fig. 2). Fiber areas of type I, IIA, and IIC in the proximal part of Normal-OL group were significantly larger than Normal-Cont group, however, the type IIB fiber area did not differ (Fig. 2). Fiber areas of the plantaris muscle in hypox rats $14 \mathrm{~d}$ after compensatory overload are shown in Fig. 3. Fiber areas of type I, IIB, and IIC in the distal part of Hypox-OL group were significantly larger than Hypox-Cont group (Fig. 3). Fiber areas of type I and IIC in the proximal part of Hypox-OL group were significantly larger than Hypox-Cont group, however, the type IIB fiber area did not differ (Fig. 3).

Figure 4 shows IGF-I mRNA expression in plantaris muscle at 3 (a) and $14 \mathrm{~d}$ (b) after compensatory overload. IGF-I mRNA expressions in the distal and proximal parts in Normal-OL group were significantly greater than in Normal-Cont group at $3 \mathrm{~d}$ after the
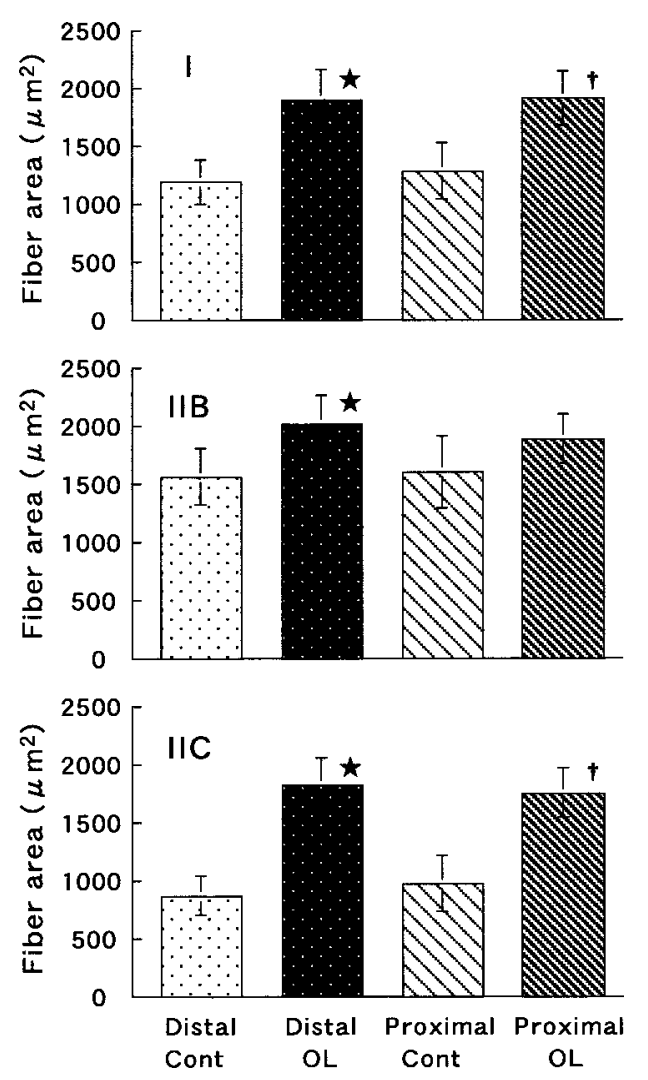

Fig. 3. Muscle fiber areas of plantaris in hypox rats $\mathbf{1 4} \mathbf{d}$ after compensatory overload. ${ }^{\star} p<0.05$ vs. DistalCont; ${ }^{\dagger} p<0.05$ vs. Proximal-Cont.

compensatory overload (Fig. 4a), but at $14 \mathrm{~d}$, IGF-I mRNA expressions in the distal and proximal parts in the Normal-OL group conversely were significantly decreased in comparison with in Normal-Cont group (Fig. 4b). IGF-I mRNA expressions in the distal and proximal parts in Hypox-OL group were significantly greater than in Hypox-Cont group 3 and $14 \mathrm{~d}$ after the compensatory overload (Fig. 4a, b). The IGF-I mRNA expressions in distal parts in Normal-OL and HypoxOL groups $3 \mathrm{~d}$ after the compensatory overload were significantly greater than IGF-I mRNAs in the proximal parts, respectively (Fig. 4a).

Figure 5 shows GH receptor mRNA and GH-binding protein mRNA expressions in plantaris muscle $3 \mathrm{~d}$ after compensatory overload. GH receptor mRNA and GH-binding protein mRNA expressions in the proximal parts in normal and hypox rats were significantly greater than those in the distal parts, respectively. GH receptor mRNA and GH-binding protein mRNA expressions in the distal and proximal in Normal-OL group were significantly lower than in Normal-Cont group. GH receptor mRNA and GH-binding protein mRNA expressions in the distal and proximal parts in Hypox-OL group were significantly lower than in Hypox-Cont group (Fig. 5). 

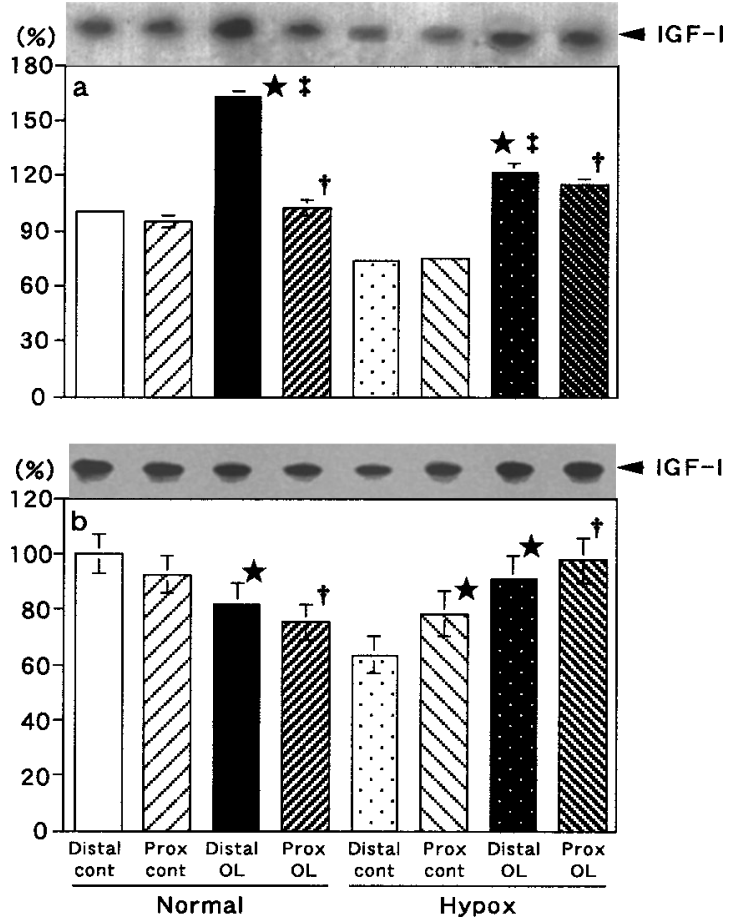

Fig. 4. IGF-I mRNA expression in plantaris muscle at 3 (a) and $14 \mathrm{~d}(\mathrm{~b})$ after compensatory overload. The data were expressed as a percentage of the value obtained from distal control in normal rats. ${ }^{\star} p<0.05$ vs. Distal-Cont in normal or hypox rats; ${ }^{\dagger} p<0.05$ vs. Proximal-Cont in normal or hypox rats; ${ }^{\ddagger} p<0.05$ vs. Proximal-OL in normal or hypox rats.

$\mathrm{GH}$ receptor mRNA and GH-binding protein mRNA expressions in plantaris muscle at $14 \mathrm{~d}$ after compensatory overload aere shown in Fig. 6. GH receptor mRNA expression in the proximal parts in Normal-OL was significantly greater than that in the distal part, however, GH receptor mRNA and GHbinding protein mRNA expressions in the proximal parts in hypox rats were decreased or unchanged, in comparison with those in the distal parts, respectively. $\mathrm{GH}$ receptor mRNA and GH-binding protein mRNA expressions in the distal and proximal in Normal-OL group were significantly lower than in Normal-Cont group. GH receptor mRNA and GH-binding protein mRNA expressions in the distal and proximal parts in Hypox-OL group were almost disappeared (Fig. 6).

\section{DISCUSSION}

This study found the degree of compensatory-overload-induced hypertrophy in plantaris muscle to be independent of hypophysectomy. Also, IGF-I mRNA expressions in the distal and proximal parts of plantaris muscle in normal and hypox rats were significantly increased at $3 \mathrm{~d}$ after the compensatory over-

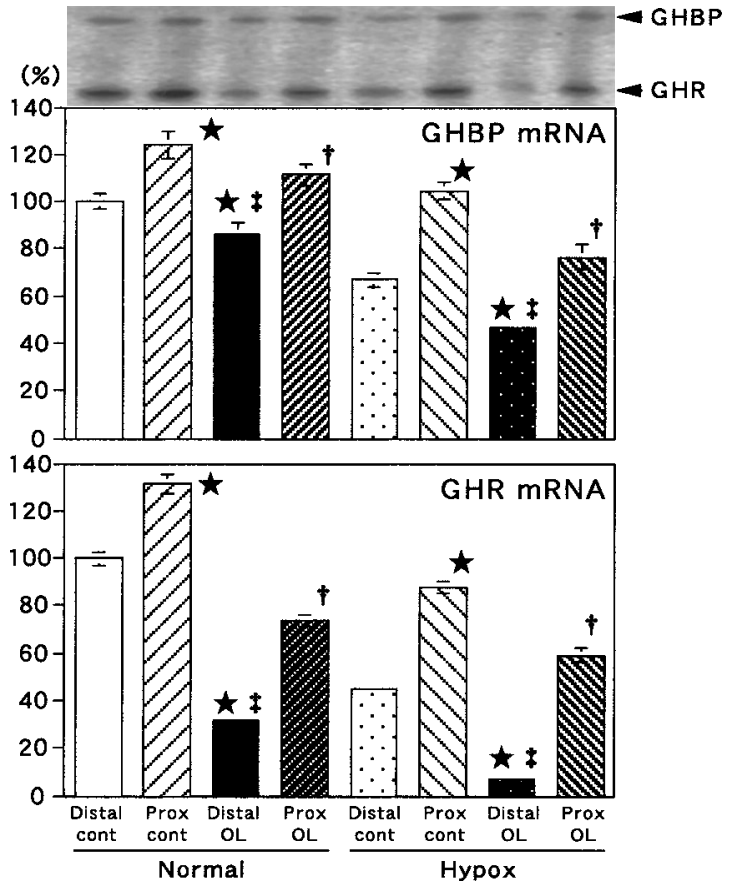

Fig. 5. GH binding protein mRNA and $\mathrm{GH}$ receptor mRNA expressions in plantaris muscle at $\mathbf{3} \mathbf{d}$ after compensatory overload. The data were expressed as a percentage of the value obtained from distal control in normal rats. ${ }^{\star} p<0.05$ vs. Distal-Cont in normal or hypox rats; ${ }^{\dagger} p<0.05$ vs. Proximal-Cont in normal or hypox rats; ${ }^{\ddagger} p<$ 0.05 vs. Proximal-OL in normal or hypox rats.

load. These results suggest that compensatory hypertrophy of plantaris muscle is independent of pituitary $\mathrm{GH}$, and that IGF-I's independence of expression from pituitary GH plays an important role in compensatory hypertrophy. These observations support the previous reports that found GH-independent IGF-I to be of importance in muscle hypertrophy $[13,14]$.

In this study, the area of type IIB fiber in the proximal parts of plantaris muscle in normal and hypox rats did not change after compensatory overload. However, all the fiber areas measured in the distal parts of normal and hypox rats increased significantly, showing that hypertrophy in the distal part of the plantaris muscle following compensatory overload exceeds that in the proximal part. Region-specific hypertrophy in a muscle has been reported in studies on exercised humans [5] and functionally overloaded animals [4]. A possible explanation for the region-specific hypertrophy following compensatory overload is that the muscle fibers of the different parts of a muscle are recruited at different levels for various movements. Distal fibers in lateral gastrocnemius muscle may be mainly recruited for slow stepping exercise, whereas proximal fibers may be recruited in equal or greater amount for moderate to fast stepping exercise [6]. 


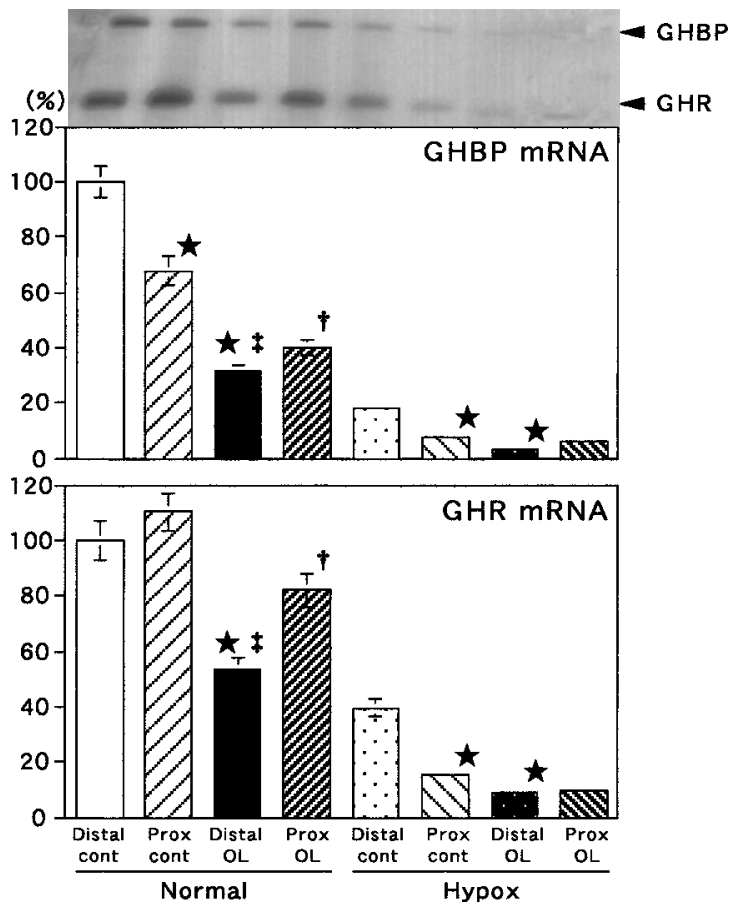

Fig. 6. GH binding protein $m R N A$ and $G H$ receptor mRNA expressions in plantaris muscle at $14 \mathrm{~d}$ after compensatory overload. The data were expressed as a percentage of the value obtained from distal control in normal rats. ${ }^{\star} p<0.05$ vs. Distal-Cont in normal or hypox rats; ${ }^{\dagger}$ $p<0.05$ vs. Proximal-Cont in normal or hypox rats; ${ }^{\ddagger} p<0.05$ vs. Proximal-OL in normal or hypox rats.

Muscle fibers along the proximal-distal axis in a muscle have different recruitment patterns [7]. Another explanation for the greater hypertrophy in the distal part of the plantaris muscle is that it may result from the change in the recruitment pattern in relation to the operating procedure used to induce the compensatory overload. Such procedure in this study was the removal of the distal half of the gastrocnemius and soleus muscles. We directly observed in the dissection that after the removal of the distal half, the remaining gastrocnemius and soleus muscles bonded to the proximal part of the plantaris muscle. Consequently, whereas the proximal part of plantaris muscle contracts with the bonded gastrocnemius and soleus muscles, the distal part of the plantaris muscle contracts independently. This difference may have caused region-specific hypertrophy of the plantaris muscle after compensatory overload in this study.

IGF-I mRNA expressions in the distal and proximal parts of the plantaris muscle were observed to be increased at $3 \mathrm{~d}$ after compensatory overload regardless of hypophysectomy. Also, in the distal part the increase in IGF-I mRNA expression was greater following compensatory overload. These results show that IGF-I mRNA expression following compensatory overload differs between the parts of a muscle, and is dependent on the hypertrophy levels in a muscle. It has been reported that IGF-I mRNA expression increases during compensatory hypertrophy [13, 14], and that the suppressed growth of skeletal muscle in hypophysectomized rats is restored by the administration of IGF-I $[8,9]$. These observations suggest that local IGF-I mRNA expression may be associated with the region-specific hypertrophy in a muscle that is induced by compensatory overload.

At $14 \mathrm{~d}$ after compensatory overload, IGF-I mRNA expressions in the distal and proximal parts increased in hypophysectomized rats, but decreased in normal rats. Thus a temporal discrepancy between IGF-I mRNA levels and muscle hypertrophy at $14 \mathrm{~d}$ after compensatory overload was observed in this study. It has been known that the changes of several mRNAs were transient and preceded the tissue growth [24, 25]. Such transience and precedence may explain the temporal discrepancy between IGF-I mRNA levels and the muscle hypertrophy.

Although the functions of $\mathrm{GH}$ receptor and $\mathrm{GH}-$ binding protein in skeletal muscle remain unclear, the existence of GH receptor in skeletal muscle is thought to be evidence of direct action by GH on skeletal muscle growth. Isgaard et al. [12] reported that GH receptor mRNA expression increased the volume of overloaded cardiac muscle. Jennische and Andersson [16] showed that the expression of GH receptor mRNA increases in skeletal muscle that is regenerating after ischemic damage. However, GH receptor mRNA and GH-binding protein mRNA expressions in this study were seen to have largely disappeared at $14 \mathrm{~d}$ after compensatory overload. Compensatory overload in this study induced region-specific hypertrophy of the plantaris muscle regardless of hypophysectomy. Muscle hypertrophy following compensatory overload occurs in GH-deficient hypophysectomized rats $[3,8$, 14], and GH-independent IGF-I plays an important role in hypertrophy $[13,14]$. These observations suggest that GH receptors in compensatory overloaded muscle may be unrelated to the hypertrophy, whereas $\mathrm{GH}$ receptors in the regenerating skeletal muscle or in cardiac muscle are related to the hypertrophy.

GH receptor mRNA and GH-binding protein mRNA expressions in the proximal parts in normal and hypox rats were greater than those in the distal parts at $3 \mathrm{~d}$ after compensatory overload. Also, at $14 \mathrm{~d}$ after compensatory overload in normal rats, the expression of GH receptor mRNA in the proximal part was higher than in the distal part. The direct action of $\mathrm{GH}$ on skeletal muscle has not been fully confirmed. However, these observations suggest that GH sensitiv- 
ity in the plantaris muscle differs between the distal and proximal parts, and that GH-related muscle growth in the proximal part is greater than in the distal part. Williams and Goldspink [26] reported that the longitudinal growth of skeletal muscle results mainly from the newly formed sarcomere at the distal end. The findings of their report suggest that the regionspecific expression of GH receptor mRNA observed in this study has a physiological function.

Whereas GH receptor mRNA and GH-binding protein mRNA expressions in the proximal parts at $3 \mathrm{~d}$ after compensatory overload were higher than those in the distal part, those in the proximal parts at $14 \mathrm{~d}$ after compensatory overload in hypox rats were decreased or unchanged as compared with those in the distal part. Also, at $14 \mathrm{~d}$ after compensatory overload in Normal-Cont, GH-binding protein mRNA in the proximal part was lower than in the distal part. We could not account for all these discrepant results. However, at $14 \mathrm{~d}$ after compensatory overload in hypox rats, $\mathrm{GH}$ receptor mRNA and GH-binding protein mRNA expressions were extremely weak. This indicates that hypophysectomy at $14 \mathrm{~d}$ after compensatory overload has a large effect on $\mathrm{GH}$ receptor mRNA and GHbinding protein mRNA expressions. Consequently, it is thought that the large effect of hypophysectomy modified the expressions of GH receptor and GHbinding protein mRNAs in distal and proximal parts. Also, if different sensitivities for hypophysectomy exist in distal and proximal parts, this may also influence the expressions of $\mathrm{GH}$ receptor and GH-binding protein mRNAs.

\section{REFERENCES}

1. Goldberg AL: Work-induced growth of skeletal muscle in normal and hypophysectomized rats. Am J Physiol 213: 1193-1198, 1967

2. Timson BF: Evaluation of animal models for the study of exercise-induced muscle enlargement. J Appl Physiol 69: 1935-1945, 1990

3. Yamaguchi A, Sakuma K, Morita I, Soya H, Takeda H, and Katsuta S: Changes in fibre types in rat soleus and plantaris muscles following hypophysectomy and compensatory overload. Acta Physiol Scand 158: 89-95, 1996

4. Sakuma K, Yamaguchi A, and Katsuta S: Are regionspecific changes in fibre types attributable to nonuniform muscle hypertrophy by overloading. Eur J Appl Physiol 71: 499-504, 1995

5. Roman WJ, Fleckenstein J, Stray-Gundersen J, Alway SE, Peshock R, and Gonyea WJ: Adaptations in the elbow flexors of elderly males after heavy-resistance training. J Appl Physiol 74: 750-754, 1993

6. English AW: An electromyographic analysis of compartments in cat lateral gastrocnemius muscle during unrestrained locomotion. J Neurophysiol 52: 114-125, 1984

7. Hutchison DL, Roy RR, Bodine-Fowler S, Hodgson JA, and Edgerton R: Electromyographic (EMG) amplitude patterns in the proximal and distal compartments of the cat semitendinosus during various tasks. Brain Res 479: 56-64, 1989

8. Guler H-P, Zapf J, Scheiwiller E, and Froesch ER: Recombinant human insulin-like growth factor I stimulates growth and has distinct effects on organ size in hypophysectomized rats. Proc Natl Acad Sci USA 85: 4889-4893, 1988

9. Adams GR and McCue SA: Localized infusion of IGF-I results in skeletal muscle hypertrophy in rats. J Appl Physiol 84: 1716-1722, 1998

10. Ullman $M$ and Oldfors $A$ : Skeletal muscle regeneration in young rats is dependent on growth hormone. J Neurol Sci 106: 67-74, 1991

11. Fryburg DA, Gelfand RA, and Barrett EJ: Growth hormone acutely stimulates forearm muscle protein synthesis in normal humans. Am J Physiol 260: E499E504, 1991

12. Isgaard J, Wahlander $H$, Adams MA, and Friberg P: Increased expression of growth hormone receptor mRNA and insulin-like growth factor-I mRNA in volume-overloaded hearts. Hypertension 23: 884-888, 1994

13. Adams GR and Haddad F: The relationships among IGF-1, DNA content, and protein accumulation during skeletal muscle hypertrophy. J Appl Physiol 81: 25092516, 1996

14. DeVol DL, Rotwein P, Sadow JL, Novakofski J, and Bechtel PJ: Activation of insulin-like growth factor gene expression during work-induced skeletal muscle growth. Am J Physiol 259: E89-E95, 1990

15. Zanconato S, Moromisato DY, Woods J, Brasel JA, Leroith D, Roberts CT Jr, and Cooper DM: Effect of training and growth hormone suppression on insulinlike growth factor I mRNA in young rats. J Appl Physiol 76: 2204-2209, 1994

16. Jennische $\mathrm{E}$ and Andersson GL: Expression of GH receptor mRNA in regenerating skeletal muscle of normal and hypophysectomized rats. An in situ hybridization study. Acta Endocrinol 125: 595-602, 1991

17. Koyama R: A simple method of hypophysectomy in rats. Endocrinol Jpn 9: 321-323,1962

18. Ianuzzo CD and Chen V: Metabolic character of hypertrophied rat muscle. J Appl Physiol 46: 738-742, 1979

19. Gollnick PD, Parsons D, and Oakley CR: Differentiation of fiber types in skeletal muscle from the sequential inactivation of myofibrillar actomyosin ATPase during acid preincubation. Histochemistry 77: 543-555, 1983

20. Brooke $\mathrm{MH}$ and Kaiser KK: Muscle fiber types: how many and what kind? Arch Neurol 23: 369-379, 1970

21. Chomczynski $P$ and Sacchi N: Single step method of RNA isolation by guanidium thiocyanate-phenol-chloroform extraction. Anal Biochem 162: 156-159, 1987

22. Friedberg T, Grassow MA, and Oesch F: Selective detection of chromes P450 an other members of the P450IIB family by the RNase A protection assay. Arch Biochem Biophys 279: 167-173, 1990

23. Fujikawa T, Yoshizato $H$, Soya $H$, and Nakashima $K$ : Dynamic alterations in growth hormone receptor mRNA 


\section{A. YAMAGUCHI et al.}

levels rat brain during stress tolerance. Endocrine $\mathrm{J} 43$ (Suppl): s119-s122, 1996

24. Marsh DR, Criswell DS, Carson JA, and Booth FW: Myogenic regulatory factors during regeneration of skeletal muscle in young, adult, and old rats. J Appl Physiol 83: 1270-1275, 1997

25. Marsh DR, Criswell DS, Hamilton MT, and Booth FW:
Association of insulin-like growth factor mRNAs expression with muscle regeneration in young, adult, and old rats. Am J Physiol 273: R353-R358, 1997

26. Williams PE and Goldspink G: The effect of immobilization on the longitudinal growth of striated muscle fibres. J Anat 116: 45-55, 1973 